\title{
HIGH-CHARGE SMECTITE IN SPANISH "RAÑA" SOILS
}

\author{
Francisco José aragoneses and María Teresa Garcia-González \\ Centro de Ciencias Medioambientales, CSIC, Serrano I15 Ddo. \\ 28006-Madrid, Spain
}

\begin{abstract}
Abstrat-In a study of "rana" soils of central Spain, hydroxy-interlayered 2: 1 clay mincrals were idenlified in the upper horizons and high-charge smectite in the lower horizons, with kaolinire the most abundant phyilosilicate. The high-charge smectite showed a basal spacing of $18 \AA$ on $\mathrm{Mg}$-satnration and glycerol solvation and $10 \AA$ on K-saturation and air-drying. It is concentrated in the coarse fractions and appears to be basically a beidellite in the fine-silt fractions and a montmonilonite in the clay fractions. Pre-existing illite was probably transtormed into hydroxy-interlayered $2: 1$ clays in the surface honzons, whereas high-change smectite formed in the deeper horizons. These minerals, which were apparently not stable in the existing soil conditions, wcre the first stage in the degradation process of illite. The stable mineral in these soil profiles was kaolinitc.
\end{abstract}

Key Words-High-charge smectite, Hydroxy-interlayer clays, Lilite. Layer charge, "Raña" soils, Soil clay.

\section{INTRODUCTION}

The weathering of $\mathrm{K}$ '-bearing micas has been known for some time to result in the formation of expandabie 2:1 clay mincrals. Bray (1937) pointed out that the removal of $\mathrm{K}$ from miea prodnces a beidellite-type mineral having cation-exchange properties. The process is usually interpreted as a mica-to-vermiculite-tosmectite continuous sequencc. According to Kittrick (1973), vermiculite may 1ransform from mica inilially, but it is a fast-forming, unstable intermediate. During this transformation, interlayer $\mathrm{K}^{+}$is replaced by hydrated cations, and the layer charge is reduced (Fanning et al, 1989).

Some artificial weathering studies, however, have shown that micas have been directly trausformed to smectite (Huff, 1972; Robert, 1973). Smectites weathered from micas are likely to be tetrahedrally substituled, approaching the beidellite end member in chemical composition (Özkan and Ross, 1979). They usually show a behavior midway between those of normal smectite and vermiculite, and have been called highcharge smectile, low-charge vermiculite, or transformation smectite. High-charge smectite has becn defined as a smectite that shows a basal spacing of $18 \AA$ on $\mathrm{Mg}$-saturation and glyccrol-solvation and $10 \AA$ on K-saturation and air drying (Egashira et al., 1982). Highcharge swelling phyllosilicates have been reported in many soils as a weathering product of mica (Robert et al., 1974; Sroch and Sikora, 1976; Nash, 1979; Egashira and Tsuda, 1983; Senkayi et al., 1983, 1985; Badraoui et al., 1987). The formation of high-charge smectite may require dioctahedral mica, whereas trioclahedral mica is likeiy to be trausformed into vermiculitc (Egashira aud Tsuda, 1983). The importance of the high-charge 2:1 minerals for crop production has recently becu outlined by Chen et al. (1989) duc to their capability for fixing $\mathrm{NH}_{4}{ }^{\prime}$ and $\mathrm{K}^{\prime}$.

Copyriglt \& 1991 , The Clay Mincrals Socicty
The word "raña" is used for alluvial-fan type formations, Pliocene-Quaternary aged, originating from shale-quartzitc regions, and associated with significant tcconic readjustments, which range from the phase of leveliing and filliug of Tertiary basins to the deepening of the oldest terrace. Such areas are flat or have only gently inclined surfaces; they coutain highly devcloped soils having marked hydromorphic characteristics. In Spain, such "raña" material covers an arca of about 400,000 ha and is found in large areas of the Ibcrian peninsula. Spanish "raña"-type soils were studied by Espejo (1985, 1987), Vicente el al. (1986), RodríguczPascual et al. (1987), Garcia-González and Aragoneses (1988, 1990), Sánchez-Camazano et al. (1988), and Aragoneses (1990).

The aim of the present paper is to report the occurrence of high-charge smcetite in Spanish "raûa" soils and to relate the properties of the smectite to its genesis in an altemp1 to increase our understanding of the processes of formation and development of these formations.

\section{MATERIALS AND METHODS}

The zouc sludicd is in the Province of Guadalajara in the northeast ccuter of the Ibcrian pcuinsula. The stucly centred around the Membrillera, Robledo de Corpes, Bustares, and Mcsa del Pino areas, subsequeutly abbreviated as ME, RC, BU, and MP, respectively (Figure l). The soil profiles in the last threc areas were developed from "raña" formations, whcreas those in ME area originated from materials that clearly do not belong 10 the oldest 1errace or to raña, but which represents a transition area between the so-called "upper-raña" (zones above $1100 \mathrm{~m}, \mathrm{RC}, \mathrm{BU}$, and MP) and "lower-raña" (zones below $930 \mathrm{~m}$, southern ME). All the profiles studied were deep, acidic, had marked hydromorphic characteristics and low organic matter 


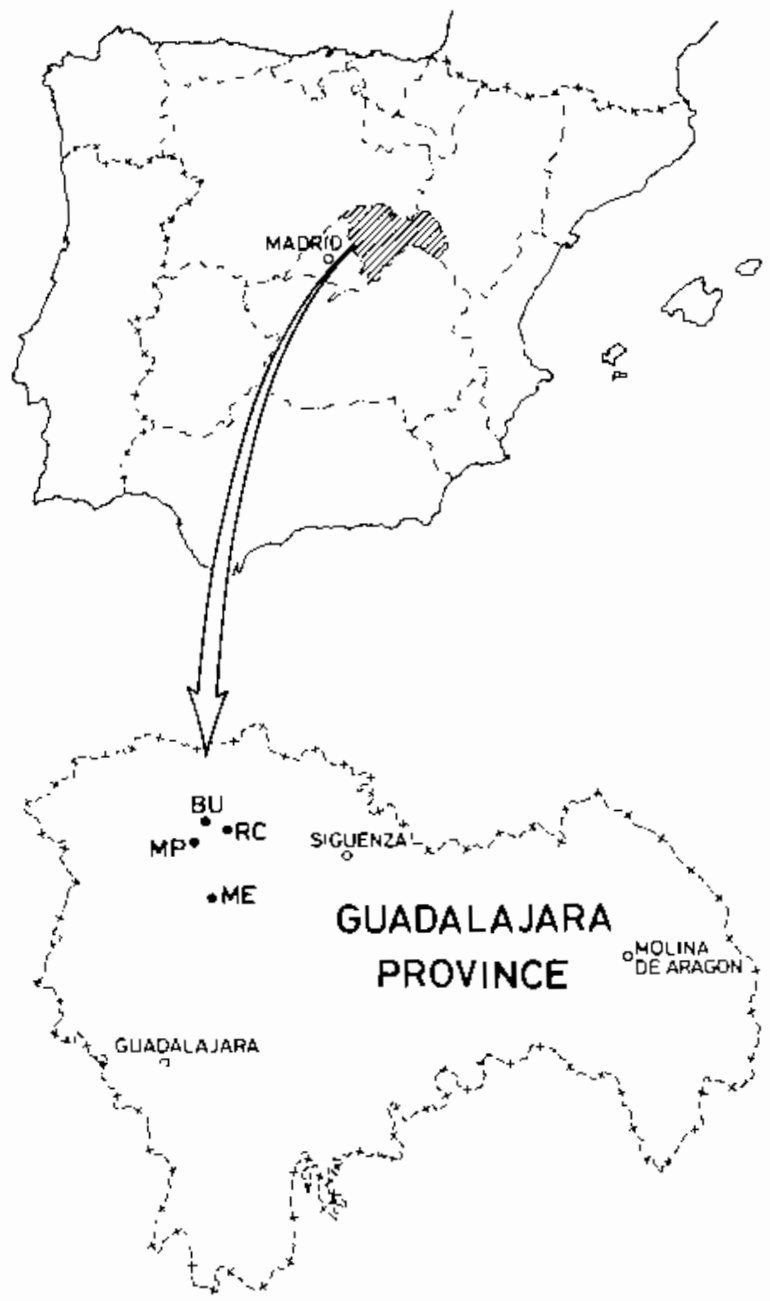

Figure 1. Map showing location of sludy area.

conten1, werc usually very stony, especially on the surface, aud showed a high degree of wcathering (see also Table 1).

Samples were 1aken from each horizon of the four studied profiles. The clay fraction $(\leq 2 \mu \mathrm{m})$ and the finc-silt fraction (2-8 $\mu \mathrm{m})$ were cxtracted by mcans of sedimentation. The size fractious were 1reated with hydrogen pcroxide to eliminate the organic mat1er.
Three differen1 treatments were carried out for Mgsaturation of the clay and fine-silt fractions: (1) triple washing with $0.5 \mathrm{M} \mathrm{Mg}$ chloride; in the first treatment, the sample was kept in contacl with the solution for $24 \mathrm{hr}$ (sMg procedure); (2) double washiug with $1 \mathrm{M}$ $\mathrm{Na}$ acetate and then four imes with $0.5 \mathrm{M} \mathrm{Mg}$ chloride (Na-sMg procedure); the first treatment with eaeh salt lasted for $24 \mathrm{hr}$; and (3) the same as (2), but kecping the temperature at $70^{\circ} \mathrm{C}$ in a water bath (70 Na-sMg procedure). All samples of the clay fraction and of the fine-silt fraction containing suhstantial smectite were Mg-saturated using the normal procedure (sMg). The olher treatments werc used only for those samples for which the $\mathrm{sMg}$ procedure was not effective.

K-salurated samples of the smeeti1e-rich horizons were prepared by treating them twice with $1 \mathrm{M} \mathrm{Na}$ acclate and then four times with $1 \mathrm{M} \mathrm{K}$ chloride at $70^{\circ} \mathrm{C}$ (70Na-sK procedure). Selected samples from the surface horizons were $\mathrm{K}$-saturated using the normal procedure (sK) to oblain more information ahout possiblc interlavered hydroxide shee1s.

Mineralogical identification was made hy X-ray powder diffraclion (XRD), using a Philips PW 1130 diffraclometer equiped with a graphite mollochroma10r (C.uK $\alpha$ radialiou). XRD patterns were obtained from Mg-sa1.urated clay aud fine-silt fractions of cach sample using: (1) raudom powder, and the following oriented aggregates: (2) air dricd; (3) cthylenc-glyeol solvated; (4) glyccrol solvated; (5) heated to $300^{\circ} \mathrm{C}$ for $3 \mathrm{hr}$; and (6) heated $10500^{\circ} \mathrm{C}$. for $3 \mathrm{hr}$. For the $\mathrm{K}$-saturated samples, oricnted aggregates were recorded (1) air dried at RH 55\%; (2) ethylene-glycol solvated; and (3) glycerol solvaled. Oriented specimens of the lon-homoionic clay and fine-silt fractious (natural untreated samples) were also studied.

Samples haviug a higher smectite couleut were also analyzed for the Hofmanu and Klemen (1950) effect. They were washed three times with $1 \mathrm{M} \mathrm{Li}$ chloride and then dialyzed to remove exeess salt (sLi procedure). XRD pattems of air-dried and glycerol-solvated specimcus werc recorded. The samples were placed in a porcelain crucible and heated to $270^{\circ} \mathrm{C}$ ovemight (270sLi procedure), and XRD pattems were recorded again (Grcene-Kclly test, 1953).

The fille-silt fraction of ouc horizon per profite was

Tablc 1. Main characteristics of the soil profiles.

\begin{tabular}{|c|c|c|c|c|c|c|}
\hline Profile- & $\begin{array}{c}\text { Alutude } \\
(\mathrm{m})\end{array}$ & $\begin{array}{c}\text { Depth } \\
\text { (cm) }\end{array}$ & Profile horizons & $\begin{array}{l}\text { Classification } \\
\text { (USDA, 1975) }\end{array}$ & $\mathrm{11}_{2} \mathrm{PH}_{1: 2.5}^{\mathrm{pH}}$ & Drainage \\
\hline $\mathrm{ME}$ & 975 & 150 & $\begin{array}{l}\mathrm{AuJ}, \mathrm{Au2} \text {, Bts, E, } \\
\mathrm{Big}, 2 \mathrm{Btr}\end{array}$ & Ulic Palexeralf & Strongly acid & Poorly drained \\
\hline $\mathrm{RC}^{\prime}$ & 1140 & 110 & $\mathrm{Ap}, \mathrm{Bl}, \mathrm{Blg}, \mathrm{BC} \mathrm{tr}$ & Aquultic Hapiudalf & Very sirongly acid & Poorly drained \\
\hline $\mathrm{BL}$ & 1180 & 75 & $\mathrm{~A}, \mathrm{AB}, \mathrm{Br}, \mathrm{CBr}$ & Aquultic Hapludalf & Very strongly acid & Imperfectly draiued \\
\hline $\mathrm{MP}$ & 1130 & 110 & $\begin{array}{c}\text { Ap, } A B_{g}, B \operatorname{tg} 1 \\
\text { Big } 2, B C r\end{array}$ & Aquultic Hapludalf & Strongly acid & $\begin{array}{l}\text { Imperfectly to poorly } \\
\text { drained }\end{array}$ \\
\hline
\end{tabular}

${ }^{\prime} \mathbf{M E}=$ Membrillera, $\mathbf{R C}=$ Robledo de Corpes, $\mathrm{BU}=$ Buslares, $\mathrm{MP}=$ Mesa del Pino. 
treated with (1) sodium carbonate (Follett $e t$ al., 1965) and (2) dithionite-citrate-bicarbonate (Mehra and Jackson, 1960), to eliminate all possible cementing agents. After each 1reatmcnl the clay fraction was separatcd. XRD patterns of the oricnted clay- and finesilt subfractions were recorded: (1) air dried, (2) clhylenc-glycol solvated, (3) heated to $300^{\circ} \mathrm{C}$ for $3 \mathrm{hr}$, and (4) heated to $500^{\circ} \mathrm{C}$ for $3 \mathrm{hr}$. Some samples were previonsly $\mathrm{Mg}$-saturated using the $70 \mathrm{Na}$-sMg procedure described above.

Semiquantitative cstimations of quartz, fcldspars, goethitc, and total phyllosilicates werc obtaincd from $X R D$ random powder patterns, integrating the area of the diffraction maxima a1 $4.26,3.25,4.16$, and 4.44 $\AA$, respectively, and using the intensity factors given by Schultz (1964) and Biscaye (1965). Approximate abundances of kaolinite, illite, paragonite, smectite, and hydroxy-interlayered clay were estimated in a similar way, using the oriented aggregate patterns; peak areas at 7.2 (kaolinite), 10.0 (illite), 4.8 (paragonite), 16.9 and $14.1 \AA$ for ethylene glycolated samples (smectite and hydroxy-interlayered clay) wcre measured. Thus, given the method used, the values shown in Table 2 are not 1ruly quantitative, but were nsed only as an internal measure.

\section{RESULTS}

\section{Clay mineral identification}

The XRD patterns of the Mg-saturated samples ( $\mathrm{sMg}$ procedurc) indieate that kaolinitc, illite, and $14-\AA$ minerais are the major components of the clay and finesilt fractions of the profiles. In the surface horizons the 14- $\AA$ peak did not shift to lower angles when the sample was solvated with ethylene glycol or glycerol (Figure 2). After heating at $300^{\circ} \mathrm{C}$, that peak became a broad band, slightly shifted to lower spacings, and disappeared after heating at $500^{\circ} \mathrm{C}$. This clearly indicates she absence of chlorite. The K-saturated sample (sK procedure) clcariy showed the $14-\AA$ peak (Figure 2 ). According to Robert (1975), all these fea1nres indicate the existence of hydroxy-interlaycred $2 ; 1$ clay minerals.

In the $\mathrm{B}$ horizons the $10-\AA$ peak of some samples was markedly asymmetric towards lower angles and became more asymmetric when the sample was solvated with organic compounds. For other samples, peaks al aboul 1 1-12 $\AA$ wcre noted (Figure 3), possibly duc to either the presence of an interstratificd mincral

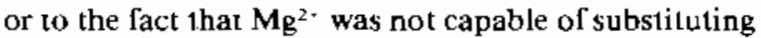
for the interlayered cation in the smectite minerals. To clarify this situation, the samples that showcd broad or diffuse reffcctions after $\mathbf{M g}$-saluration in the airdried pattern were treated by the $\mathrm{Na}$-sMg procedure. After such a trcalment (Figure 3), the 001 reflection was found at lower angles, but in some samples not as far as $14 \AA$. The treatmont was, thereforc, repeated at $70^{\circ} \mathrm{C}$ (70 Na-sMg procedure). This produced a peak

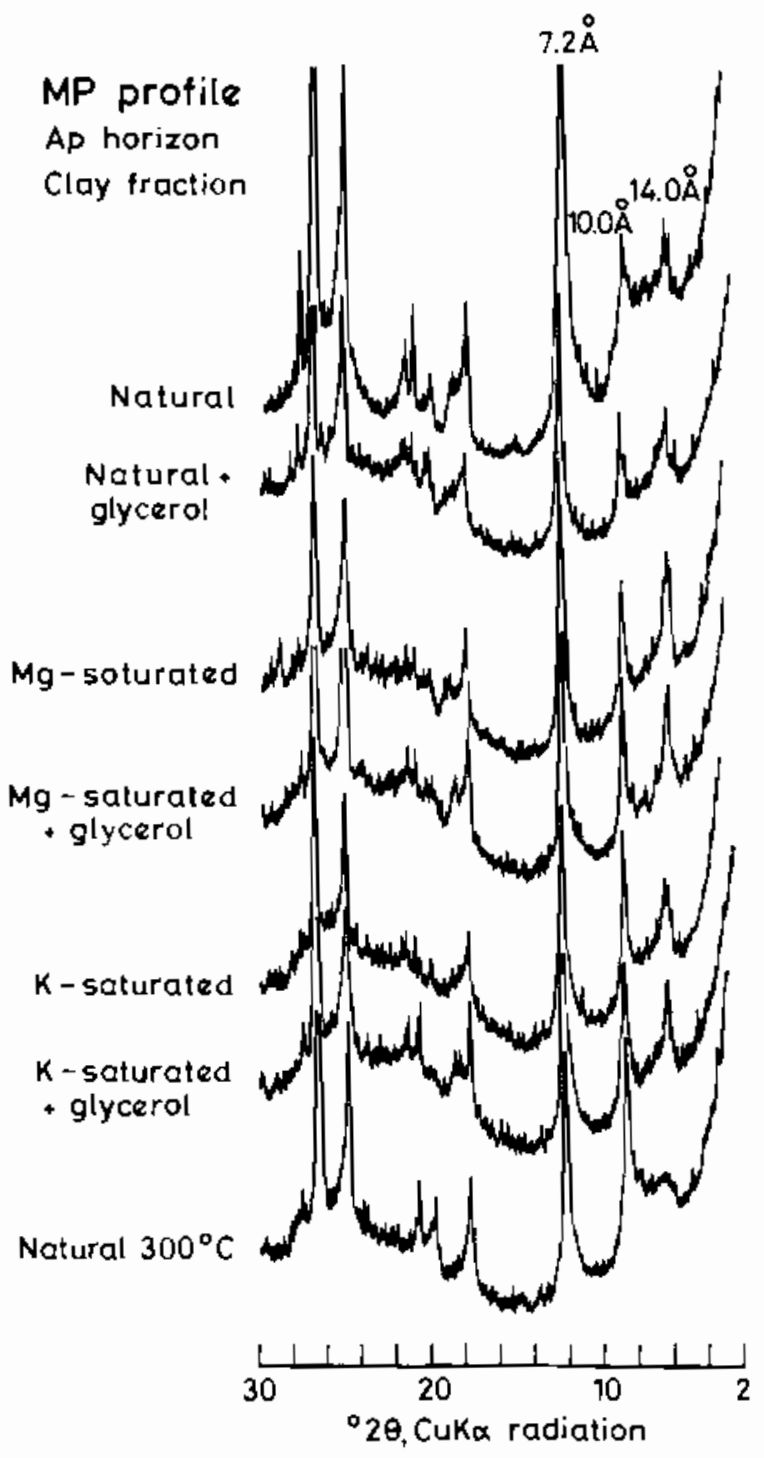

Figure 2. X-ray powder diffraction patterns of oriented aggregales after several trealments.

shifting to $14 \AA$ for the air-dried, $17 \AA$ for the ethyleneglycol-solvated, and $18 \AA$ for the glycerol-solvated specimens (Figure 3 ). Thus, the sample probably contained a smeclite in which the substitution of all intcrlayercd cations hy $\mathbf{M g}^{2+}$ was achieved only by using the $70 \mathrm{Na}-\mathrm{sMg}$ procednre.

The peaks at about $25 \AA$ in patterns of the finc-silt fraction of the $\mathrm{BCr}$ (MP protile) and 2Btr (ME profile) horizons, after the $70 \mathrm{Na}-\mathrm{sMg}$ procedure, indicate the presence of a small amount of regular interstratified mineral. The displacement of this pcak to $28 \AA$ after glycerol solvation (Figurc 3) suggests that this mineral is a regular interstratified illite/smectitc (I/S). Although in the litcrature $\mathrm{I} / \mathrm{S}$ is often reported as a mineral of 


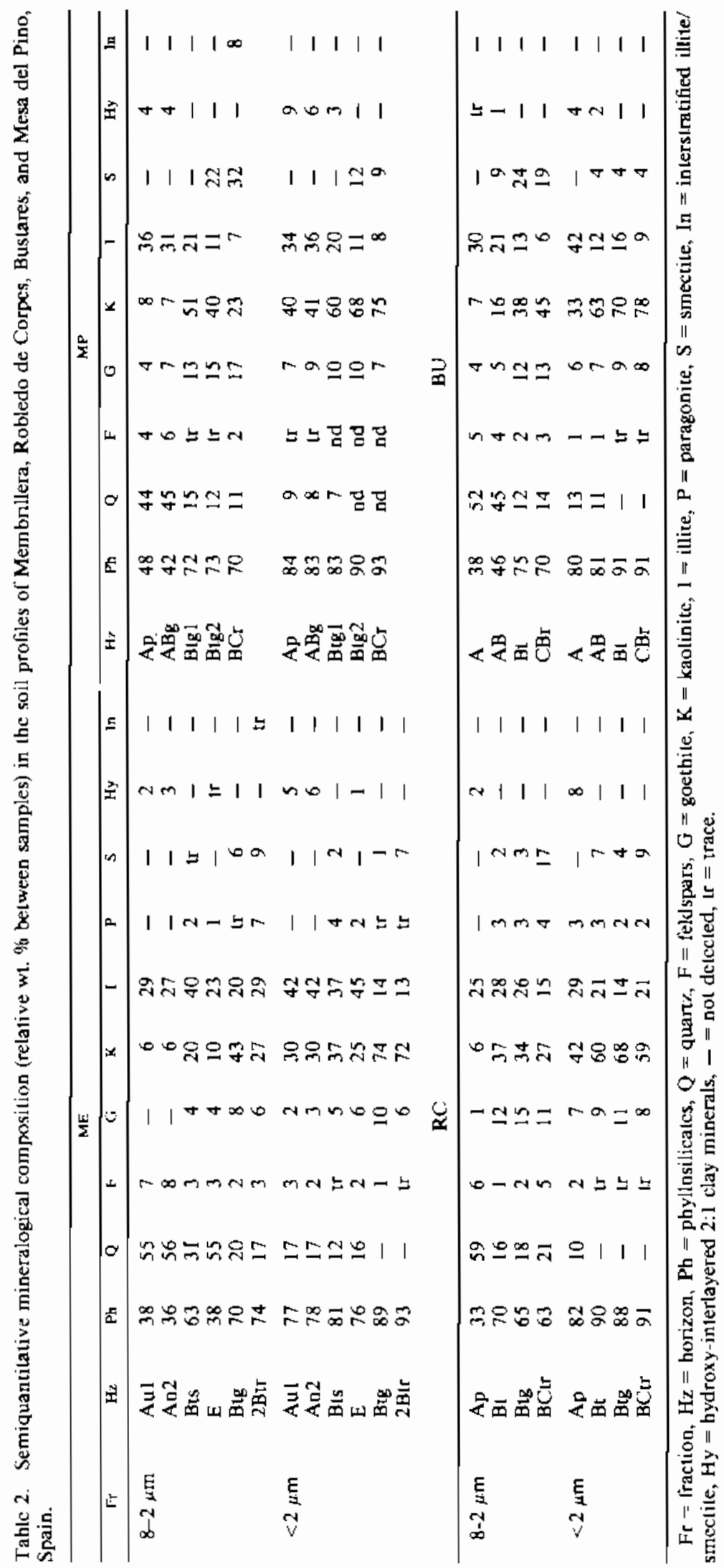



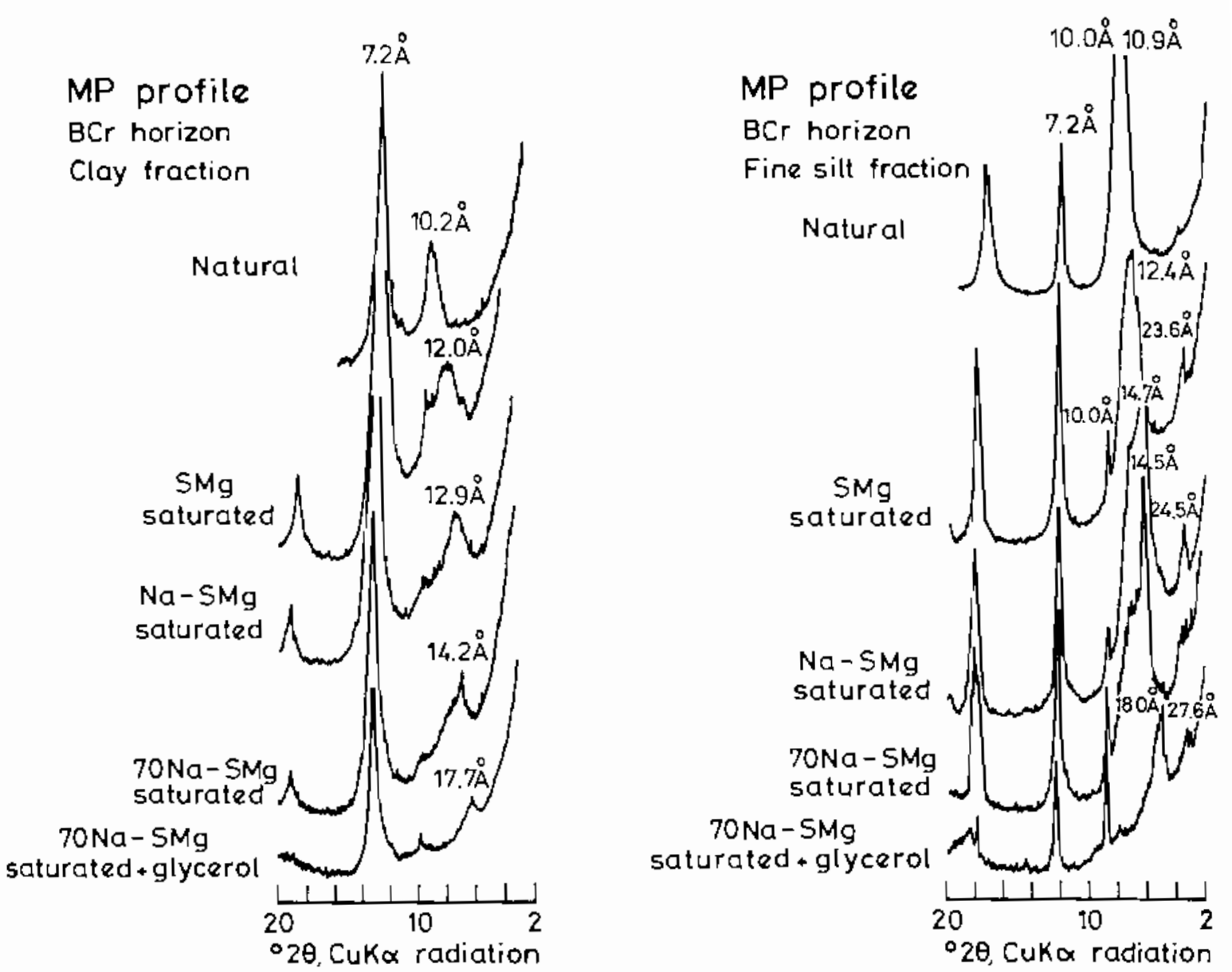

Figure 3. X-ray powder difftaction patterns of orieuted aggregates after several saturation trealments.

extremely small grain size (Środoń. 1980), here, it has been found in the fine-silt fraction only.

To obtain a better knowledge of the smectite in these soils, the samples were also studied in their natural state. The XRD patterns of most samples showed (Figure 3) cither an asymmetric peak at $10 \AA$, with asymmetry extending to $11 \AA$, or a peak at about $11 \AA$. These data suggest the existence of a K-smectite. Thus, the $\mathrm{K}$ content in these natural samples may have been responsible for the fact that the laycrs were collapsed, thereby making exchange with other cations difficult.

To dctermine the location of cationic substitution, samples of clay fractions were saturated with $\mathrm{Li}^{+}$and heated overnight at $270^{\circ} \mathrm{C}$. These samples showed no expansion after solvation with glyccrol (Figure 4), indicaling that the charge in the smcctite of the clay fraction was principally in the octahcdral shcet. In contrast, the XRD patterns of the smectite in the fine-silt iractions showed a reflection or shoulder ar $17.7 \AA$ after solvation with glycerol. Thus, beidellite was probably the dominant smeetite in the fine-silt. fraction, and montmorillonite, in the clay fraction. Important dif- ferences were noted, however, in the $10-\AA / 17-\AA$ intensity ratio of the sLi- and 270 sLi-glycerol-solvated fine-silt samples, suggesting that not all the layer charge was due to tetrahedral substitution. Octahedral cationic substitution must also have been present. The layer charge of natural 2:1 clay minerals is commonly distributed over bo1h shce1s (Tsipursky and Drits, 1984).

The degree of collapse of the basal spacing by $\mathrm{K}$-saturation and air-drying at $54 \% \mathrm{RH}$ as a critcrion for differentiating strectite from vermiculite (Harward ct al., 1969) was used in the present study. The collapse of the smectite to $10 \AA$ took place in the samples of both the clay and fine-silt fractions (Figure 5). Thus, the layer charge of this mineral was closer to that of vermiculitc and greater than would be expected for a typical smectite. The K-saturated mincral did not expand on ethylene-glycol solvation, indicating that $\mathrm{K}^{+}$ tightly fixed the layers. The mineral, therefore, behaved like a smectite (peaks at 14.0 and $17.7 \AA$ for the $\mathrm{Mg}$ saluratcd air-dried and glycerol-solvated specimens, rcspectively) having high charge, as demonstrated hy the collapsing to $10 \AA$ in the K-saturated air dricd at 

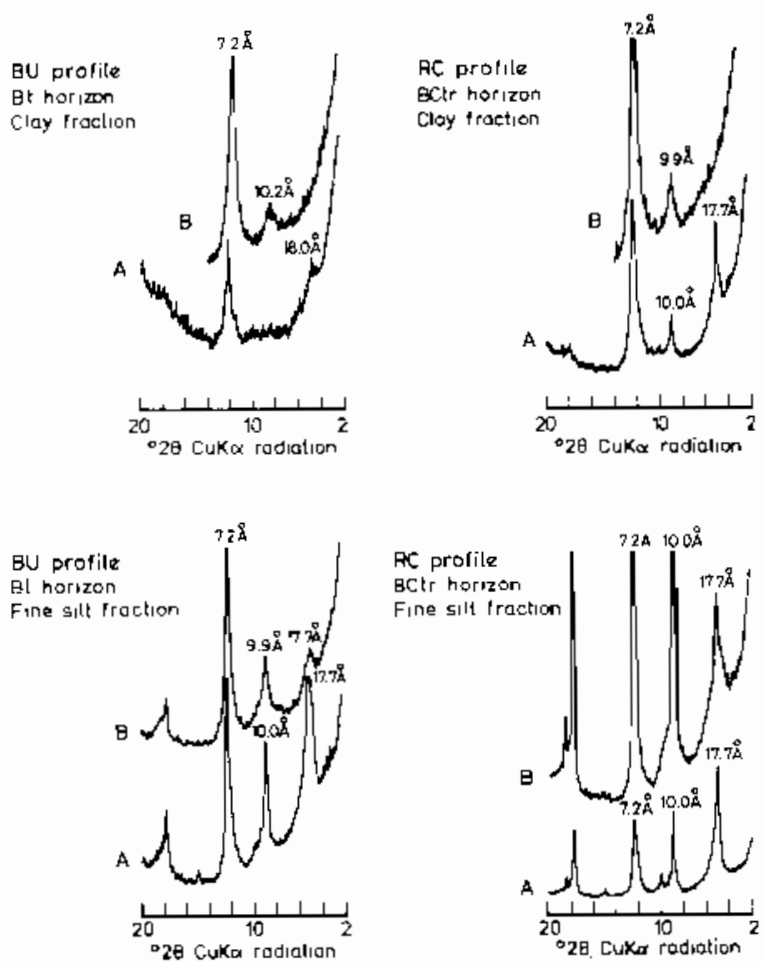

Figure 4. Greene-Kelly test applied to several samples: A, alter sLi procedure and glycerol solvation; B, alter $270 \mathrm{sLi}$ procedure and glycerol solvation.

$54 \%$ RH sample. Therefore, this mineral can be termed as a high-charge smectite (Egashira et al. 1982) having montmorillonite and beidellite characters in the clay and fine-silt fractions, respectively. This mineral was norc abundant in the fine-silt than in the clay fraction. its proportion being greater in the non-surface horizons of the MP and BU profiles.

\section{Semi-quantitative mineral composition}

Table 2 shows the mineralogical composition of the four profilcs. The phyllosilicate content in the clay fraction is high (76-93\%), with a relatively high proportion in the fine-silt fraction (33-75\%). The quartz concentration decreases markcdly with depth, inversely with the phyllosilicate content. In the deeper horizons the illite content is markcdly lcss, whereas the kaolinite content is greater. An exccption is the eluvial $E$ horizon from the ME profike, which is wcll delined and separate from the other horizons because of its greater content of primary minerals, eompared with those in the underlying B horizons (Garcia-González and Aragonescs, 1988).

Goethite was the only crystalline iron oxide identified in these soils, bcing concentrated in the fine fractions of the deep horizons. Small, rather uniform amounts of paragonite werc also identified in the clay fractions of the ME- and RC-profiles. as well as in the

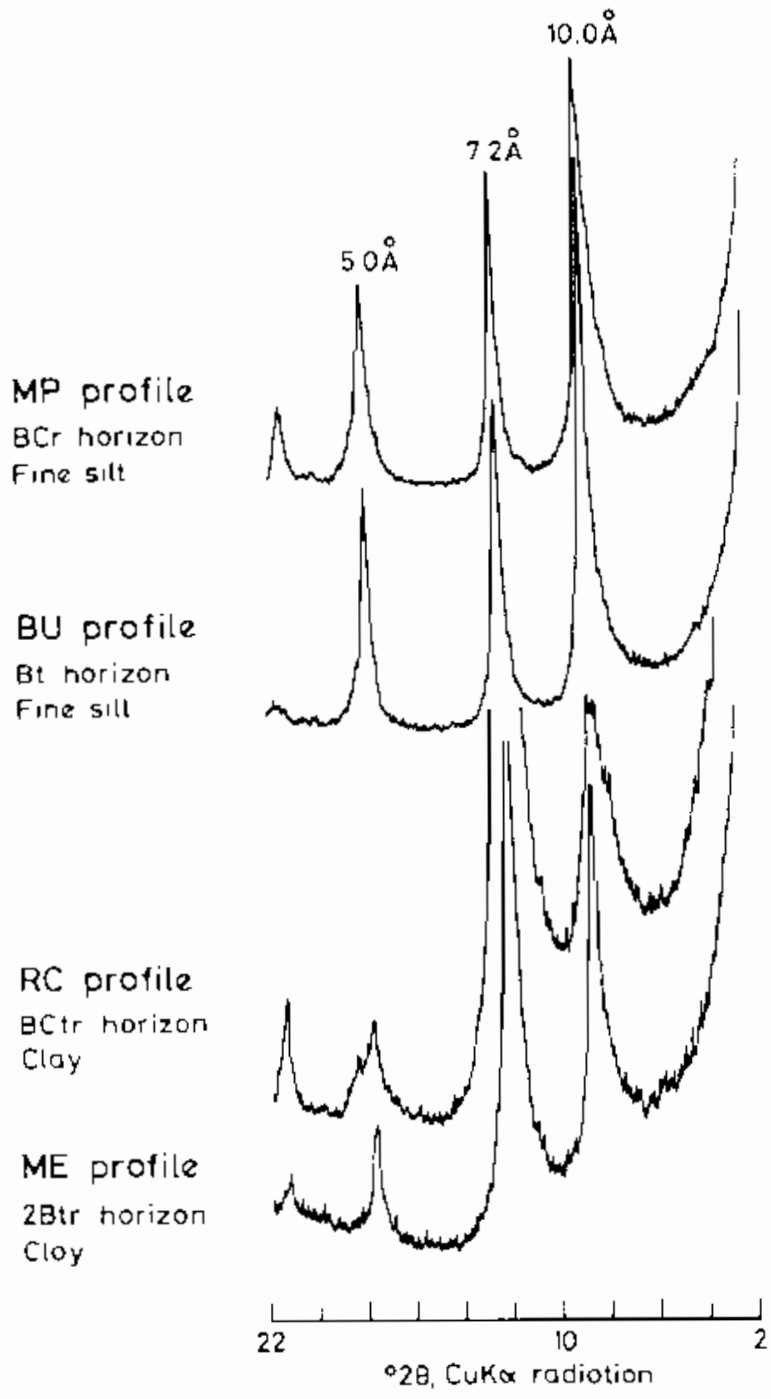

Figure 5. X-ray powder diffraction pattems of orieuted aggregates of $\mathrm{K}$-saluraled samples (70 Na-sK procedure).

fine-silt fraction (Garcia-González and Aragoneses, 1990).

The high phyllosilicate and smeclite concentrations in the fine-silt fraction might possibly have been dne to the existence of aggregating agents. Iron oxide particles, for example, can react with clay particles via coulombic or non-coulombic forces (Schwertmann, 1988). On the other hand, siliccous and aluminous ccments commonly bind clay particles into aggregatcs (Smith and Mitchell, 1989). To ascertain the possible existence of aggregating agents, two treatments werc applied separately, one with the $\mathrm{DCB}$ reactive agent and one with sodium carbonate (to eliminate possible iron oxide and/or aluminosiliceous binding agents, respectively). Four fine-silt samples, one horizon per profile (Btg2 of MP profile, Bt of BU profile, BCtr of RC profile, and Btg of ME profile), were used. The DCB 
Table 3. Semiquantitative mineralogical composition (relauve $w$. \% between samples) of fractions extracted from a fine-sill fraclion aficr Na-carbonate treatment.

\begin{tabular}{|c|c|c|c|c|c|c|}
\hline Profile' & Henzon & $\mathbf{k}$ & I & $\mathbf{P}$ & s & In \\
\hline & & \multicolumn{5}{|c|}{ Remanent fine silt } \\
\hline $\mathrm{BU}$ & Bt & 19 & 19 & - & 28 & - \\
\hline $\mathrm{ME}$ & $2 \mathbf{B t r}$ & 26 & 3.3 & tr & 9 & $\mathrm{tr}$ \\
\hline MP & $\mathrm{BCr}$ & 25 & 10 & - & 22 & 4 \\
\hline \multirow[t]{2}{*}{$\mathrm{RC}$} & BC.lr & 27 & 47 & 4 & 17 & - \\
\hline & & \multicolumn{5}{|c|}{ Remanent clay } \\
\hline Bu & Bt & 29 & 23 & - & 13 & - \\
\hline $\mathrm{ME}$ & $2 \mathrm{Bl}$ & 20 & 43 & 1.5 & 5 & - \\
\hline $\mathbf{M P}$ & $\mathrm{BCr}$ & 23 & 7 & - & 32 & 3 \\
\hline RC & BC'tr & 18 & 23 & 2 & 22 & - \\
\hline
\end{tabular}

$\mathrm{K}=$ kaolinitc, $\mathrm{I}=$ illite, $\mathrm{P}=$ paragonite, $\mathrm{S}=$ smeclite, In $=$ interstratified illite/smecutc, $-=$ nol delected, $1 \mathrm{r}=$ trace.

' See Tablc 1 for abbreviations.

trcatment did not produce a noticcable amount of clay fraction. Thus, iron oxides were probably not acting as cemcnting agen1s in these samples. The sodium carbonate treatment, on the other hand, produced a considerablc amount of clay. The amount of high-charge smeclitc in the clay and remaining finc-silt fractions (both coming from the fine silt, Table 3 ) indicates that the accumulation of this mineral in the coarse fractions was nol only due to the aggregating cffect.

\section{DISCUSSION}

The high-charge smectite showed the following characteristics: (1) higher proportion in the fine silt than in the clay fraction; (2) high charge; (3) diffcult opening of the layers, possibly due to the existence of interlaminar potassium. All this suggests that this mineral was formed by the transformation of the dioctahedral mica, illitc (Rober et al, 1974; Senkayi et al., 1983, 1985; Rubhlicke and Niederbudde, 1985). Thus, high-charge smectite was apparently an unstable mineral and appeared in the initial transformation stages of the illite. During weathering, the octahedral charge increascd, changing the smectite character from bcidellite (fincsilt fraction) towards montmorillonite (clay fraction).

The hydroxy-interlayered 2:1 clay minerals may have bcen formed from the illite transformation (April ef al., 1986; Farmer $e$ t al., 1988) aud its presence (Tablc 2) may be restricted to the surface horizons (Barnhisel and Berisch, 1989). Illitc was probably transformed into hydroxy-interlayered $2: 1$ clays in the surfacc horizons, whcreas high-charge smectite was formed in the deeper horizons.

The $\mathbf{I} / \mathbf{S}$ mineral found in two of the profiles probably rcprescnts a separate illite transformation. Srodoń and Eberl (1984) suggested that $\mathrm{I} / \mathrm{S}$ can form by the dcgradation of detrital illitic material. Removal of $\mathbf{K}^{\prime}$ from illite-containing soils leads to the degradation of illite and the formation of smectitc and interstratificd material (Tributh et al., 1987).

The stable mineral in these soil conditious was kaolinite. Its small grain size suggests that it was formed through a neoformation process (Koppi et al., 1987), although a transformation from micas or expandable 2:1 minerals cannot be discardcd. To understand the accumulation of kaolinite in the B horizons, the illuviation process should also be taken into account,

The mineralogical evolution of these soils could have bcen as follows;

\author{
coarsc fractions \\ Mica-illitc $\rightarrow$ High-charge smectite* \\ *beidellitic character
}

\section{ACKNOWLEDGMENTS}

We thank Mrs. M. P. Lázaro, Ms. I. Antón, aud Mr. A. Gómez for technical assistance, We arc grateful for the valuable suggestions given by F. A. Mumpton, editor. and the relerees. F. J. Aragonescs thanks the provision of a fellowship from the "Ministerio dc Edu" cación y Ciencia," Spain. This research was suppored by CAICYT (Spain) under Projccl No. PR84/0140/ co6.

\section{REFERENCES}

April, R. H., Hluchy, M. M., and Newton, R. M. (1986) The nature of vermiculite in Adirondack soils and till: Clays of Clay Minerals $\mathbf{3 4}, 549-556$.
Aragoneses, F. J. (1990) Geoquínica y mineralogía de las fracciones finas de suelos tipo Raìa en la provincia de Gluadalajara: Ph.D. thesis, Univ. Autónoma, Madrid, Spain. 296 pp.

Badraoui, M., Bloom, P. R., and Rust, R. H. (1987) Occurrence of high-charge beidellite in a vertic Haplaquoll of northwestern Minnesota: Soil Sct. Soc. Amer. J. \$1, 813818.

Barnhisel, R. 1. and Bertsch, P. M. (1989) Chlorites and hydroxy-interlayered vermiculite and smectite: in Minerals in Soil Environments, J. B. Dixon and S. B. Weed, eds., Soil Sci. Soc. Amer, Madison, Wisconsin, 729-788.

Biscaye, P. E. (1965) Mineralogy and sedimentation of Recent deep sea clay in the Atlantic ocean and adjacent seas and oceans: Geol. Soc. Amer. Bull. 76, 803-832.

Bray, R. M. (1937) Chemical and physical changes in soil collonds with advancing development in Illinois soils: So.l Sci. 43, 1-15. 
Chen, C. C., Tumer, F. T., and Dixon, J. B. (1989) Ammonjum fixation by high-charge smeclite in selecled Texas Gulf coast soils: Soil Sci. Soc. Amer. J. 53, 1035-1040.

Egashira, K., Dixon, J. B., and Hossner, L. R. (1982) High charge smectite from lignile overburden of east Texas: in Proc. Int. Clay Conf., Bologna and Pavia, 1981, H. van Olplien and F. Veniale, eds., Elsevier, Amsterdam, 335345.

Egashira, K. and Tsuda, S. (1983) High-clarge smectite found in weatlered granitic rocks of Kyushu: Clay ScI. 6, 67-71.

Espejo, R. (1985) The ages and soils of two levels or "Raña" surfaces in Central Spain: Geoderma 35, 223-239.

Espejo, R. (1987) The soils and ages of the "Raña" surfaces related to the Villuercas and Altamira mountain ranges (western Spain): Catena 14, 399-418.

Fanning, D.S., Keramidas, V. Z., and El-Desoky, M. A. (1989) Micas: in Minerals in Soil Environments, J. B. Dixon and S. B. Weed, eds., Soil Sci. Soc. Amer, Madison, Wisconsin, $551-634$

Farmer, V. C., Smith, B. F. L., Wilson, M. J., Loveland, P. J, and Payton, R. W. (1988) Readily-extractable hydroxyaluminium interlayers in clay- and silt-sized vermiculite: Clay Miner. 23, 271-277.

Folletl, E. A. C., McHardy, W. S., Milchell, B. D., and Smith, B. F. L. (1965) Chemical dissolution techniques in the study of soil clays: Clay Miner. Bull. 6, 23-24.

Garcia-González, M. T. and Aragoneses, F. J. (1988) Relación entre la mineralogía y el tamaño de partícula cu suelos sobre formaciones pliocuaternarias en el área de Membrillera (Guadalajara): in Segundo Congr. Nac. Ciencla del Suelo, Sevilla, Spain, 1988. C. Roquero, ed., Madrid. Spain, 529-534.

García-Gonzálcz, M. T. and Aragoneses, F. J. (1990) Paragonite in Spanish "Raña" soils: J. Soil Sci. 41, 3l3-323.

Grecnc-Kelly, R. (1953) The identification of montmorillonitoids in clays: $J$. Soil Sci. 4, 233-237.

Harward, M. E., Carstea, D. D., and Sayegh, A. M. (1969) Properties of vermiculites and smectites: Expansion and collapse clays: Clay Miner. 16, 437-447.

Hofmann, V. U. aud Klemen, R. (1950) Verlust der Auslauschlähigkeil von Lithinm-ionen an Bentonit durch Erhitrung: Z. Anorg. Chem. 262, 95-99.

Hluff, W. D. (1972) Morphological effects on illite as a resnlt of pottassium depletion: Clays \& Clay Mincrals 20, 295301 .

Kiltrick, J. A. (1973) Mica-derived vermiculites as nnstable intermediates: Clays \& Clay Minerals 21, 479-488.

Koppi, A. J., Skjemslad, J. O., Page, D. W., and Cockayne, D.J.H. (1987) Size and change cluaracteristics ol kaolinitic soils in SE Queensland. I. Soil Sci. 38, 395-404.

Mehra, O. P. and Jackson, M. L. (1960) Iron oxide removal from solls and clays by a dithionite citrate system buffered with sodium bicarbonate: in Clays and Clay Minerals. Pros. 7 th Natl Conf., Washington, D.C., 1958, Ada Swineford, ed., Pergamon Press, New York, 317-327.

Nash, V. E. (1979) Mineralogy of soils developed on Pliocene-Pleistocene terraces of the Tombigbee river in Mississippi: Soil Soi. Sor Amer. J. 43, 616-623.

Özkan, A. 1 and Ross, G. J. (1979) Ferruginous beidellites in Turkish soils: Soil Sci. Soc. Amer. J. 43, 1242-1248.

Robert M. (1973) The experimental iransformation of mica roward smectite; relative importance of tolal charge on tetraftedral substitution: Clays \& Clay Minerals 21, 167-174.

Rober, M. (1975) Principes de détermination qualitative des minéraux argileux a l'aide des rayons X: Ann. Agron. 26, 363-399.

Roben, M., Tessier, D., Isamber, M., and Baize, D. (1974)
Evolution des glauconites el illites. Contribution a la connaissance des smectites des sols: Trans. IOth Intl. Congr. Soil Sci., Moscow. 7, N. N. I. Gorbunov and G. V. Dobrovolsky, eds., Nauka, 97-106.

Rodríguez-Paseual, C., Galván, B., and Galván, J. (1987) Miucralogical properties of soils on "raña" formations in the province of Guadalajara (Spain): in Proc. 6th European Clay Groups, Sevillo, Spoin, 1987, E. Galán, J. L. PérezRodriguez, and J. Comejo, eds., Sevilla, Spain, 467-469.

Rülılicke, G, and Niederbudde, E. A. (1985) Determination of layer-charge density of expandable 2:1 clay minerals in soils and loess sediments using the alkylammonium method: Clay Miner. 20, 291-300.

Sánchez-Camazano, M.. Sánche7-Martin, M. J., and Vicente, M. A. (1988) Características de la fracción arcilla en los suelos de raña al norte del Sistema Central: in Segundo Congr. Nac. Ciencia del Suelo, Sevilla. Spain, 1988, C. Roquero. ed., Madrid, Spain, 548-553.

Schultz, L. G. (1964) Quantitative interpretation of mineralogical composition from X-ray and chemical data for the Pierre Shale: U.S. Geol. Surv. Prof. Pap., 391-C. ClC.31.

Schwertmann, U. (1988) Some properties of soil and synthetic iron oxides: in Iron in Soils and Clay Minerals, J. W. Stucki, B. A. Goodman, and U. Schwertmann, eds., D. Reidel, Dordrecht, The Netherlands, 203-250.

Senkayi, A. L., Dixon, J. B., Hossner, L. R., and Viani, B. E. (1983) Mineralogical translormations during weathering of lignite overburden in eası Texas: Clay. \& Clay Minerals 31, 49-56.

Senkayi, A. L., Dixon, J. B., Hossner, L. R., and Kippenberger, L. A. (1985) Layer charge evaluation of expandable soil clays hy an alkylammonium method: Sorl Sci. Soc. Amer. J. 49, 1054-1060.

Smith, B. F. L, and Mitchell, B. D. (1989) Clraracterization of poorly ordered minerals by selective chemical methods: in $A$ Handbook of Determinative Methods in Clay Mineralogy. M. J. Wilson, ed., Blackue, Glassworth, United Kingdom. 275-294.

Środon, J. (1980) Precise identification of illite/smectite interstralifications by X-ray powder diffraction: Clays \& Clay Minerals 28, 40l-411.

Srodoń, J. and Eberl, D. D. (1984) Illite: in Micas, Reviews in Minerology, 13, S. W. Bailey, ed.. Mineralogical Soc. Amer., Washington, D.C., 495-544.

Stoch, L. and Sikora, W. (1976) Transformalions of micas in the process of kaolinitization of granites and gneisses: Clays \& Clay Minerals 24, $156-162$.

Tribulh, H., Boguslawski, E. V., Lieres, A. V., Steffens, D., and Mengel, K. (1987) Effect of polassium removal by crops on transformation of illitic clay minerals: Soil $S c i$. 143, 404-409.

Tsipurski, S. L. and Drits, V. A. (1984) The distribution of octahedral cations in the 2:1 layers of dioc1ahedral smectites studied by oblique texture electron diffraction: Clay Miner. 19, 177-193.

USDA (1975) Soll Taxonomy: Agricultural IIandbook, No. 436, U.S. Gov, Print. Office, Washington, D.C.. 754 pp.

Vicente, M. A., Molina, E., and García-Rodriguez, M. P. (1986) Minerological study of the $\leq 2 \mu \mathrm{m}$ clay fraction of raña 1ype soils of the northem Meseta (Spain): in Trans. 13th Congr. Int. Soc. Soil Sci., Hamburg, 1986, K. H. Harge, ed., lnt. Soc. Soil Sci.. Wageningen, 1490-1491.

(Received 14 May 1990; accepted 19 November 1990; Ms. 2008) 